ISSN 0258-7122 (Print), 2408-8293 (Online)

Bangladesh J. Agril. Res. 43(3): 489-497, September 2018

\title{
EFFECT OF PLANTING DENSITY ON YIELD AND YIELD ATTRIBUTES OF LOCAL AROMATIC RICE VARIETIES
}

\author{
J. HALDER ${ }^{1}$, G. M. ROKON ${ }^{2}$, M. A. ISLAM ${ }^{3}$ \\ N. SALAHIN ${ }^{4}$ AND M. K. ALAM ${ }^{4}$
}

\begin{abstract}
An experiment was conducted at the Agronomy Field of Patuakhali Science and Technology University, Dumki, Patuakhali from June to December, 2013 to find out the effect of variety and planting density on the yield and yield attributing characters of local aromatic rice. The experiment was laid out in a factorial randomized complete block design with three replications, which consisted of three local aromatic rice varieties (Chinigura, Shakhorkhora and Kalizira) and four planting densities were viz. $\mathrm{S}_{1}(25 \mathrm{~cm} \times 20 \mathrm{~cm}), \mathrm{S}_{2}(20 \mathrm{~cm} \times 20 \mathrm{~cm}), \mathrm{S}_{3}(20$ $\mathrm{cm} \times 15 \mathrm{~cm})$ and $\mathrm{S}_{4}(20 \mathrm{~cm} \times 10 \mathrm{~cm})$. The results revealed that the local aromatic rice var. Shakhorkhora variety produced the highest number of grains per panicle (131) and 1000-grain weight (13.8 g), consequently higher grain $\left(2.63 \mathrm{t} \mathrm{ha}^{-1}\right)$, followed by Kalizira $\left(2.56 \mathrm{t} \mathrm{ha}^{-1}\right)$ and straw yield $\left(4.21 \mathrm{t} \mathrm{ha}^{-1}\right)$. One the other hand, higher number of tillers per hill (14.8), number of grains per panicle (140 nos.) were found in $20 \mathrm{~cm} \times 20 \mathrm{~cm}$ spacing with higher grain yield.
\end{abstract}

Keywords: Local aromatic rice, variety, planting density, rice yield.

\section{Introduction}

Rice (Oryza sativa L.) being the world's most widely consumed cereal grain play an unique role in satisfying global hunger (IRRI, 2004). Bangladesh, an agrobased country, depends on agriculture for most of her economic activities. The total area and production of rice in Bangladesh is about 11.75 million hectare and 34.4 million metric ton, respectively in the year 2013/14 (BBS, 2015). Although the geographical, climatic and ethnic conditions of Bangladesh are favorable for year-round rice cultivation, the national average of rice yield is low (2.91 ton ha $\left.{ }^{1}\right)$ compared to other rice growing countries (BBS, 2015). A dense population of crop may play the negative role to have the maximum yield from the limited resources. Optimum plant spacing ensures optimum number of plants per unit area which lead to yield contributing characters and ultimately grain yield. Optimum plant spacing facilitates plants to grow properly, utilizing more solar radiation and soil nutrients (Mia et al., 1993; Bhowik et al., 2012). When the

${ }^{1}$ ACT (Science) DSHE, SEQAEP Ministry of Education, Peoples' Republic of Bangladesh; ${ }^{2}$ Agricultural Development Officer, International Maize and Wheat Improvement Center (CIMMYT), Bangladesh; ${ }^{3}$ ACI-IRRI PPP Project, Bangladesh; ${ }^{4 \& 5}$ Scientific Officer, Soil Science Division, Bangladesh Agricultural Research Institute (BARI), Gazipur-1701, Bangladesh. 
planting density exceeds the optimum level, competition among the plants for light and nutrients becomes severe. Consequently, the growth slows down and the grain yield decreases. The rice economy in Bangladesh can be changed by improving production technologies of aromatic fine rice. Among the rice varieties, scented or aromatic rice is popular in Asia and has gained wider acceptance in Europe and United States of America because of their good flavor and texture. Export of aromatic and fine rice from Bangladesh made a significant rise from 1100 tons in 2002 to 3300 tons in 2003, but the volume is still far below the potential demand of 4 million Bangladeshi living abroad. The demand of aromatic rice for internal consumption and also for export is increasing day by day (Das and Baqui, 2000). Plant spacing is one of the crop management activities which govern all of the components of plant need for their growth and yield. Plant spacing directly affects the normal physiological activities through intra-specific competition. Different crops and even different cultivars of a crop respond physiologically differently to plant spacing due to their differential requirement of light, space, oxygen, carbon dioxide, nutrients etc. (Oad et al., 2001). Chinigura, Shakhorkhora and Kalizira are three popular aromatic rice varieties but there is not sufficient information regarding optimum spacing for these varieties. So, the present experiment was undertaken to find out the suitable local aromatic variety and optimum spacing for higher grain yield of rice varieties.

\section{Materials and Methods}

The experiment was conducted at the department of Agronomy field of Patuakhali Science and Technology University, Dumki, Patuakhali with geographical location of $22^{\circ} 26^{\prime} \mathrm{N}$ latitude and $90^{\circ} 22^{\prime} \mathrm{E}$ longitude at an elevation of $1.5 \mathrm{~m}$ above the sea level, during the period from June 2013 to December 2013 in the aman season. The field of the experimental site belonged to the Ganges Tidal Floodplain (AEZ- 13) which was characterized by non-calcareous Grey Floodplain soil with silty clay texture. The soil was mildly acidic and nonsaline. The soil was loamy in texture and having soil $\mathrm{pH}$ ranges from 6.0 to 6.8. Organic matter content was low (1.1\%). The experiment was laid out in a factorial Randomized Complete Block Design (RCBD) with three replications. The treatments were : Factor A: Variety- Chinigura $\left(\mathrm{V}_{1}\right)$, Shakhorkhora $\left(\mathrm{V}_{2}\right)$, Kalizira $\left(\mathrm{V}_{3}\right)$ and Factor B: Planting density- $25 \mathrm{~cm} \times 20 \mathrm{~cm}\left(\mathrm{~S}_{1}\right), 20 \mathrm{~cm} \times 20 \mathrm{~cm}\left(\mathrm{~S}_{2}\right), 20$ $\mathrm{cm} \times 15 \mathrm{~cm}\left(\mathrm{~S}_{3}\right), 20 \mathrm{~cm} \times 10 \mathrm{~cm}\left(\mathrm{~S}_{4}\right)$. On July 1, 2013, 30-day-old rice seedlings were transplanted into the experimental plots. The recommended fertilizer dose was $\mathrm{N}_{90} \mathrm{P}_{20} \mathrm{~K}_{50} \mathrm{~S}_{7.5} \mathrm{~B}_{2}$ and $\mathrm{Zn}_{2} \mathrm{~kg} \mathrm{ha}^{-1}$, respectively. Urea was applied in three equal parts, whereby one-third of the urea and the entire amount of triple superphosphate (TSP), murate of potash (MOP), and gypsum were applied during final land preparation; one-third of the urea was applied at the maximum vegetative growth stage (30 days after transplanting [DAT]); and one-third of the 
urea was applied before the panicle initiation stage of Boro season rice (45 DAT). Though the season was monsoon, supplemental irrigation was used to keep the paddy field well flooded until the rice plants reached maturity. These were applied at $1,15,28,40,54,63$, and 78 DAT, with a total of $28 \mathrm{~cm}$ of irrigation water being applied during rice growth. Weeding was performed at 30 DAT. Precautionary measures were taken at every stage of crop production using natural methods of pest and disease management, such as light traps, the placement of sticks for birds to stand on, and the removal of disease-infected plants at an early stage of infection, removing any need for chemical and herbicide use. The T. aman rice was harvested on 3 November 2013. The data were collected from two $1 \mathrm{~m}^{2}$ area selected randomly during transplanting of rice. All data regarding yield and yield attributes were collected from the quadrates, which then converted to yield in ton per hectare. Initial soil samples from plots of the experiment were collected from $0-15 \mathrm{~cm}$ soil depth and were analyzed in Soil Science laboratory of Patuakhali Science and Technology University, Dumki, Patuakhali. Right after collection of samples, soils were oven-dried and then sieved to clean off foreign materials. The soil samples were then analyzed for soil textural class, $\mathrm{pH}$ and organic carbon according to Black (1965), Ghosh (1983) and Jackson (1973), respectively. The collected data on growth parameters, yield contributing characters and yield of aromatic rice varieties under different spacing were analyzed statistically by using SPSS Inc. (Version 21, USA) and mean separation was done by LSD test.

\section{Results and Discussion}

The effect of variety on plant height of rice at 50 and 80 day after transplanting (DAT) along with at harvest stage was found significant (Table 1). At 50 DAT, Kalizira was the tallest $(79.7 \mathrm{~cm})$ which was statistically similar to Shakhorkhora $(79.3 \mathrm{~cm})$ and Chinigura was the shortest $(77.4 \mathrm{~cm})$ among the three varieties. At 80 DAT and harvest stage Shakhorkhora produced the tallest plant whereas Chinigura produced the shortest plant (Table 1). Number of tillers per hill was also significantly influenced by variety. Among the three varieties, Shakhorkhora produced the highest number of tillers per hill at 50 and 80 DAT (11.4 and 12.1, respectively) whereas the lowest number of tillers per hill was produced by Chinigura (10.1 at 50 DAT and 11.2 at 80 DAT), shown in Table 1. This confirms the report of Islam et al. (2013) and Sarkar et al. (2014), who reported the variable effect of variety on the number of effective tillers hill $^{-1}$. The variations in plant height and number of effective tillers hill ${ }^{-1}$ among the varieties were probably due to heredity or varietal characters.

Plant height at different stages (50,80 DAT and at harvest) was statistically different for planting density. The wider planting density $S_{1}(25 \mathrm{~cm} \times 20 \mathrm{~cm})$ produced the tallest plant $(86.0 \mathrm{~cm}$ at 50 DAT and $134 \mathrm{~cm}$ at 80 DAT and 160 $\mathrm{cm}$ at harvest), which was statistically similar to $20 \mathrm{~cm} \times 20 \mathrm{~cm}$ spacing (Table 
1). The shortest plants were observed from closest planting density $S_{4}(20 \mathrm{~cm} \times$ $10 \mathrm{~cm})$. Number of tillers per hill differed significantly due to different planting densities. Planting density $S_{2}(20 \mathrm{~cm} \times 20 \mathrm{~cm})$ produced the highest number of tillers per hill (13.9 and 14.8, respectively) at 50 DAT and 80 DAT. The closest planting $(20 \mathrm{~cm} \times 10 \mathrm{~cm})$ density produced the lowest number of tillers per hill (8.0 and 9.0, respectively) at 50 DAT and 80 DAT, shown in Table 1. The study of Tyeb et al. (2013) confirms the influence of planting density on plant height and number of tillers hill ${ }^{-1}$.

Table 1. Effect of variety and spacing on yield and yield attributes of aromatic rice

\begin{tabular}{|c|c|c|c|c|c|c|c|}
\hline \multirow{2}{*}{ Treatments } & \multicolumn{3}{|c|}{ Plant height $(\mathrm{cm})$} & \multicolumn{2}{|c|}{ No of tiller/hill } & \multicolumn{2}{|c|}{ Lodging (\%) } \\
\hline & $50 \mathrm{DAT}$ & 80 DAT & $\begin{array}{c}\text { At } \\
\text { harvest }\end{array}$ & $50 \mathrm{DAT}$ & 80 DAT & $\begin{array}{l}\text { Milking } \\
\text { stage }\end{array}$ & Harvest \\
\hline \multicolumn{8}{|c|}{ Effect of variety } \\
\hline $\mathrm{V}_{1}$ & 77.4 & 127 & 153 & 10.1 & 11.2 & 36.3 & 40.0 \\
\hline $\mathrm{V}_{2}$ & 79.3 & 131 & 155 & 11.4 & 12.1 & 28.7 & 30.3 \\
\hline $\mathrm{V}_{3}$ & 79.7 & 129 & 154 & 10.9 & 11.7 & 21.5 & 24.3 \\
\hline $\mathrm{LSD}_{0.05}$ & 1.03 & 1.08 & 1.43 & 0.82 & 0.85 & 3.02 & 5.77 \\
\hline $\mathrm{CV} \%$ & 1.54 & 0.98 & 1.10 & 8.92 & 8.57 & 12.0 & 8.39 \\
\hline \multicolumn{8}{|c|}{ Effect of spacing } \\
\hline \multirow[b]{2}{*}{ Spacing } & \multicolumn{3}{|c|}{ Plant height $(\mathrm{cm})$} & \multicolumn{2}{|c|}{ No of tiller/hill } & \multicolumn{2}{|c|}{ Lodging (\%) } \\
\hline & $50 \mathrm{DAT}$ & 80 DAT & At harvest & $50 \mathrm{DAT}$ & 80 DAT & $\begin{array}{l}\text { Milking } \\
\text { stage }\end{array}$ & Harvest \\
\hline$S_{1}$ & 86.0 & 134 & 160 & 13.0 & 13.8 & 47.2 & 49.6 \\
\hline $\mathrm{S}_{2}$ & 85.2 & 134 & 160 & 13.9 & 14.8 & 29.3 & 38.8 \\
\hline $\mathrm{S}_{3}$ & 73.2 & 125 & 150 & 9.4 & 10.4 & 23.9 & 25.0 \\
\hline $\mathrm{S}_{4}$ & 70.8 & 126 & 146 & 8.0 & 9.00 & 22.8 & 24.6 \\
\hline $\mathrm{LSD}_{0.05}$ & 1.18 & 1.24 & 1.65 & 0.94 & 0.98 & 3.49 & 6.66 \\
\hline $\mathrm{CV}(\%)$ & 1.54 & 0.98 & 1.10 & 8.92 & 8.57 & 12.0 & 8.39 \\
\hline
\end{tabular}

Legend: $\mathrm{V}_{1}=$ Chinigura; $\mathrm{V}_{2}=$ Shakhorkhora and $\mathrm{V}_{3}=$ Kalizira; $\mathrm{S}_{1}=25 \mathrm{~cm} \times 20 \mathrm{~cm} ; \mathrm{S}_{2}$ $=20 \mathrm{~cm} \times 20 \mathrm{~cm} ; \mathrm{S}_{3}=20 \mathrm{~cm} \times 15 \mathrm{~cm} ; \mathrm{S}_{4}=20 \mathrm{~cm} \times 10 \mathrm{~cm}$. LSD=Least significant difference; $\mathrm{CV}=\mathrm{Co}$-efficient of variance; DAT = Days after transplanting.

The results showed that yield and yield attributes of aromatic rice by interaction effect of variety and planting density was not significantly varied.

The effect of variety on lodging percentage was found significant. The lodging percentage was significant at milking stage as well as harvest stage among different varieties. The highest lodging was recorded in case of Chinigura for both of the stages and the lowest lodging was found in Kalizira (Table 1). That varietal difference has influence on lodging of rice was also found by Ookawa 
and Ishihara (1993) who found that difference in cell wall components of different varieties affect bending stress of the culm in relation to lodging resistance in rice.

Plant density also showed significant influence on the lodging percentage of local aromatic rice. The highest lodging percentage (47.2\%) was recorded in wider spacing $25 \mathrm{~cm} \times 20 \mathrm{~cm}$ spacing at milking stage, which continued up to harvest stage $(49.6 \%)$. The lowest lodging percentage (22.8\% at milking stage and $24.6 \%$ at harvest stage) was in narrower spacing $(20 \mathrm{~cm} \times 10 \mathrm{~cm})$, which was statistically similar to $20 \mathrm{~cm} \times 15 \mathrm{~cm}$, respectively both at milking stage $(23.9 \%$ at milking stage and harvest stage $(25.0 \%)$ as presented in Table 1. Islam and Hossain (2002) found similar result of lodging. They found higher lodging with plants transplanted with wider spacing.

The panicle length varied significantly among varieties. It was observed that Shakhorkhora produced the longest panicle $(25.5 \mathrm{~cm})$ which was statistically similar to Kalizira $(25.1 \mathrm{~cm})$ and the shortest panicle was observed in the variety Chinigura $(24.7 \mathrm{~cm})$, shown in Table 2 . The result also showed that variety had significant effect on number of grains per panicle. Variety Shakhorkhora gave significantly the highest number of grains per panicle (131) and the lowest grains per panicle (114) were produced by Kalizira (Table 2). Likewise, variety had significant effect on 1000-grain weight. Shakhorkhora produced the highest 1000 -grain weight $(13.8 \mathrm{~g})$ and the lowest 1000 -grain weight was produced by Chinigura (12.6 g), shown in Table 2. Islam et al. (2013) and Sarkar et al. (2014) confirm our results of the variable effect of variety on panicle length, grains per panicle and 1000-grain weight.

The panicle length was affected significantly under different planting densities. It was observed that the panicle length was the longest $(26.8 \mathrm{~cm})$ at $20 \mathrm{~cm} \times 20 \mathrm{~cm}$ spacing, which was statistically similar to $25 \mathrm{~cm} \times 20 \mathrm{~cm}$ spacing $(26.4 \mathrm{~cm})$ and the shortest panicle $(22.4 \mathrm{~cm}$ ) was found at $20 \mathrm{~cm} \times 10 \mathrm{~cm}$ spacing (Table 2). Planting density also showed significant effect on number of grains per panicle. It was observed that the planting density $S_{1}(20 \mathrm{~cm} \times 20 \mathrm{~cm})$ produced the highest number of grains per panicle (140). The lowest number of grains per panicle (107) was produced by the closer planting density $S_{4}(20 \mathrm{~cm} \times 10 \mathrm{~cm})$, as displayed in Table 2 . The result revealed that planting density had also significant effect on 1000-grain weight. It was observed that $25 \mathrm{~cm} \times 20 \mathrm{~cm}$ spacing produced the highest 1000-grain weight (14.9 g) and the lowest 1000grain weight $(11.3 \mathrm{~g})$ was recorded from the closest spacing $(20 \mathrm{~cm} \times 10 \mathrm{~cm})$, shown in Table 2. Similar result was found by Lu et al. (2008). The result has also similarity with the result of Ao et al. (2008) and Gopal et al., (1999) who found that yield contributing characters of rice like panicle length, grains per panicle and 1000-grain yield were very much influenced by densities of planting of rice seedlings. 
Table 2 Effect of variety and spacing on yield and yield attributes of aromatic rice

\begin{tabular}{|c|c|c|c|c|c|c|}
\hline Treatments & $\begin{array}{l}\text { Length of } \\
\text { panicle } \\
(\mathrm{cm})\end{array}$ & $\begin{array}{l}\text { Grains/ } \\
\text { panicle }\end{array}$ & $\begin{array}{l}1000- \\
\text { grain } \\
\text { weight } \\
(\mathrm{g})\end{array}$ & $\begin{array}{l}\text { Grain yield } \\
\text { (t/ha) }\end{array}$ & $\begin{array}{l}\text { Straw } \\
\text { yield } \\
\text { (t/ha) }\end{array}$ & $\begin{array}{c}\text { Harvest } \\
\text { index }(\%)\end{array}$ \\
\hline \multicolumn{7}{|l|}{ Effect of variety } \\
\hline $\mathrm{V}_{1}$ & 24.7 & 124 & 12.6 & $2.25 \mathrm{~b}$ & 3.92 & 36.5 \\
\hline $\mathrm{V}_{2}$ & 25.5 & 131 & 13.8 & $2.63 \mathrm{a}$ & 4.21 & 38.5 \\
\hline $\mathrm{V}_{3}$ & 25.1 & 114 & 12.9 & $2.56 \mathrm{a}$ & 4.05 & 38.7 \\
\hline $\mathrm{LSD}_{0.05 \%}$ & 0.74 & 4.43 & 0.49 & 0.12 & 0.17 & 2.4 \\
\hline $\mathrm{CV} \%$ & 3.49 & 4.26 & 4.46 & 5.50 & 5.57 & 4.43 \\
\hline \multicolumn{7}{|l|}{ Effect of spacing } \\
\hline Spacing & $\begin{array}{c}\text { Panicle } \\
\text { length } \\
(\mathrm{cm})\end{array}$ & $\begin{array}{l}\text { Grains/ } \\
\text { panicle }\end{array}$ & $\begin{array}{l}1000- \\
\text { grain } \\
\text { weight } \\
(\mathrm{g})\end{array}$ & $\begin{array}{l}\text { Grain yield } \\
\text { (t/ha) }\end{array}$ & $\begin{array}{l}\text { Straw } \\
\text { yield } \\
\text { (t/ha) }\end{array}$ & $\begin{array}{c}\text { Harvest } \\
\text { index }(\%)\end{array}$ \\
\hline $\mathrm{S}_{1}$ & 26.4 & 132 & 14.9 & 2.40 & 4.19 & 36.4 \\
\hline $\mathrm{S}_{2}$ & 26.8 & 140 & 14.6 & 2.87 & 4.38 & 39.6 \\
\hline $\mathrm{S}_{3}$ & 24.7 & 112 & 11.5 & 2.38 & 3.95 & 37.6 \\
\hline $\mathrm{S}_{4}$ & 22.4 & 107 & 11.3 & 1.92 & 3.72 & 34.0 \\
\hline $\operatorname{LSD}_{0.05 \%}$ & 0.86 & 5.12 & 0.57 & 0.44 & 0.33 & 2.6 \\
\hline $\mathrm{CV}(\%)$ & 3.49 & 4.26 & 4.46 & 5.50 & 5.57 & 4.43 \\
\hline
\end{tabular}

Legend: $V_{1}=$ Chinigura; $V_{2}=$ Shakhorkhora and $V_{3}=$ Kalizira; $S_{1}=25 \mathrm{~cm} \times 20 \mathrm{~cm} ; S_{2}$ $=20 \mathrm{~cm} \times 20 \mathrm{~cm} ; \mathrm{S}_{3}=20 \mathrm{~cm} \times 15 \mathrm{~cm} ; \mathrm{S}_{4}=20 \mathrm{~cm} \times 10 \mathrm{~cm}$. LSD=Least significant difference $; \mathrm{CV}=$ Co-efficient of variance; DAT $=$ Days after transplanting.

Variety had significant effects on grain yield of local aromatic rice (Table 2). It was observed that Shakhorkhora produced significantly the highest grain yield (2.63 $\left.\mathrm{t} \mathrm{ha}^{-1}\right)$, which was statistically similar to Kalizira $\left(2.56 \mathrm{t} \mathrm{ha}^{-1}\right)$. The lowest grain yield was obtained from Chinigura $\left(2.25 \mathrm{t} \mathrm{ha}^{-1}\right)$. Straw yield was not differed significantly among the local aromatic rice varieties (Table 2). However, the highest straw yield (4.21 $\left.\mathrm{t} \mathrm{ha}^{-1}\right)$ was observed in Shakhorkhora which was statistically identical with Kalizira $\left(4.05 \mathrm{t} \mathrm{ha}^{-1}\right)$ and the lowest straw yield was found in Chinigura (3.92 $\left.\mathrm{t} \mathrm{ha}^{-1}\right)$.

It was found that planting density had significant effect on grain yield of local aromatic rice varieties. It was observed that $20 \mathrm{~cm} \times 20 \mathrm{~cm}$ spacing produced the highest grain yield $\left(2.87 \mathrm{t} \mathrm{ha} \mathrm{ha}^{-1}\right)$ which was statistically different from other three planting densities. The lowest grain yield $\left(1.92 \mathrm{t} \mathrm{ha}^{-1}\right)$ was recorded from the closest spacing $(20 \mathrm{~cm} \times 10 \mathrm{~cm})$. Other two planting densities $(25 \times 20 \mathrm{~cm}$ and 
$20 \times 15 \mathrm{~cm}$ ) gave the intermediate values between $S_{1}$ and $S_{4}$ treatments (Table 2). Significant variation in straw yield was observed in local aromatic rice in respect of planting density (Table 2). The planting density $S_{2}(20 \mathrm{~cm} \times 20 \mathrm{~cm})$ produced the highest amount of straw yield $\left(4.38 \mathrm{t} \mathrm{ha}^{-1}\right)$ followed by $\mathrm{S}_{1}(20 \mathrm{~cm} \times 25 \mathrm{~cm}$, $\left.4.19 \mathrm{t} \mathrm{ha}^{-1}\right)$ and $20 \mathrm{~cm} \times 15 \mathrm{~cm}$ spacing $\left(3.95 \mathrm{t} \mathrm{ha}^{-1}\right)$. The lowest straw yield was recorded in $20 \mathrm{~cm} \times 10 \mathrm{~cm}$ spacing $\left(3.72 \mathrm{t} \mathrm{ha}^{-1}\right)$.

Variety had no significant effect on harvest index (Table 2). However, it was found that Kalizira produced the highest harvest index (38.7\%) followed by Shakhorkhora (38.5\%) and the lowest harvest index (36.5\%) was obtained from Chinigura. The variation due to the planting density was significant in terms of harvest index (Table 2). It was observed that the highest harvest index (39.6\%) was recorded from $S_{2}(20 \mathrm{~cm} \times 20 \mathrm{~cm})$ spacing and the lowest harvest index $(34.0 \%)$ was obtained from $\mathrm{S}_{4}(20 \mathrm{~cm} \times 10 \mathrm{~cm})$, whereas $\mathrm{S}_{1}(25 \mathrm{~cm} \times 20 \mathrm{~cm})$ and $\mathrm{S}_{3}(20 \mathrm{~cm} \times 15 \mathrm{~cm})$ gave second highest harvest index $(36.4 \%$ and $37.6 \%$, respectively).

The local aromatic rice variety, Shakhorkhora performs better than other local varieties (Chinigura and Kalizira) in terms of yields (Table 2). The closest spacing $20 \mathrm{~cm} \times 20 \mathrm{~cm}$ showed the best yield than other three plant densities (Table 2) due to highest plant population per unit area. Again, Shakhorkhora and $20 \mathrm{~cm} \times 20 \mathrm{~cm}$ spacing produced the highest number of tillers hill ${ }^{-1}$, the longest panicle, the highest number of grains panicle ${ }^{-1}$ which may ultimately be behind the highest grain yield. Optimum spacing produced maximum number of tillers per plant which results in higher tillers number per area (Baloch et al. 2002; Quddus and Huda 1995).

The var. Shakhorkhora had found increased panicle length as well as increased grain with planting density management. Among the planting densities, the highest grains per panicle were recorded with $20 \mathrm{~cm} \times 20 \mathrm{~cm}$ spacing. This observation was in agreement with the findings of Quddus and Huda (1995) and Rao et al. (2003) who stated that optimum planting density produced higher number of grains per panicle. The higher grain and straw yields with $20 \mathrm{~cm} \times 20$ $\mathrm{cm}$ spacing might be attributed due to higher number of plant per unit area.

The increased plant height with $25 \times 20 \mathrm{~cm}$ and $20 \times 20 \mathrm{~cm}$ planting can be attributed to the fact that widely spaced crop get more light, air and soil nutrients which facilitated the plant for proper development (Mia et al., 1990). Again, the lodging percentage increased in close spacing might be due to slender and weak plant in closer spacing resulting from malnutrition.

Based on above results, it indicates that among the three local aromatic rice varieties, Shakhorkhora and Kalizira showed higher grain yield with closer spacing $20 \mathrm{~cm} \times 20 \mathrm{~cm}$. 


\section{References}

Ao, H. J., Y. X. Fang, C. M. Xiong, Z. W. Cheng, W. Liu and Y. B. Zou. 2008. Effects of plant row spacing on yield and radiation utilization efficiency in super hybrid rice. Crop Research. 22: 263-269.

Baloch, A. W., A. M. Soomro, M. A. Javed, M. Ahmed, H. R. Bughio, M. S. Bughio, N. N. Mastoi. 2002. Optimum plant density for high yield in rice (Oryza sativa L.). Asian Journal of Plant Sciences. 1: 25-27.

BBS (Bangladesh Bureau of Statistics). 2015. Statistical Year Book of Bangladesh, Statistics Division, Ministry of Planning, Government of the people's Republic of Bangladesh, Dhaka, Bangladesh. P. 578.

Bhowmik, S. K., M. A. R. Sarkar and F. Zaman. 2012. Effect of spacing and number of seedlings per hill on the performance of aus rice cv. NERICA 1 under dry direct seeded rice (DDSR) system of cultivation. J. Bangladesh Agril. Univ. 10(2): 191195.

Black, C. A. 1965. Method of Soil Analysis Part-I and II, American Society of Agronomy, Madison, Wis, USA.

Das, T. and M. A. Baqui. 2000. Aromatic rice of Bangladesh. Aromatic Rice. Oxford \& IBH publishing Co. Pvt. Ltd. New Delhi. India, Pp. 184-187.

Ghosh, P. 1983. Institute of agriculture, Visva Bharati , Sriniketan 731-236. West Bengal, India. Indian Journal of Agricultural Research. 32: 75-80.

Gopal, M., K. Rukmini Dev and B. Lingam. 1999. Effect of seeding density level and time of nitrogen application in direct sown rice under puddled conditions. J. Res. ANGRAU.. 27: 53-55

IRRI (International Rice Research Institute). 2004. Rice Today. Intl. Rice Res. Inst. 3(3): 12-27.

Islam, M. H. and S. M. A. Hossain. 2002. Effect of Fertilization and Planting Density on the Yield of Two Varieties of Fine Rice. Pakistan Journal of Biological Sciences. 5: 513-516.

Islam, N., M. Y. Kabir, S. K. Adhikary and M. S. Jahan. 2013. Yield Performance of Six Local Aromatic Rice Cultivars. IOSR Journal of Agriculture and Veterinary Science. 6(3): 58-62.

Jackson, M. L. 1973. Soil Chemical Analysis, Constable and Co. Ltd. Prentice Hall of India Pvt. Ltd, New Delhi, India.

Lu, Y., X. J. Wang, H. C. Zhang, Z. Y. Huo, Q. G. Dai and K. Xu. 2008. A study on the high yielding mechanism of different rice cultivars under different planting density conditions. Jiangsu Journal of Agricultural Science. 1: 18-20.

Mia, M. H. N., M. A. Karim, M. S. Rahman and M. S. Islam. 1990. Performance of Nazershail mutants under different spacing. Bangladesh J. Train. and Dev. 3(2): 3134.

Miah, N., S. B. Siddique, A.U. Ahmed and M. Z. Islam. 1993. Modern rice varieties, production practices, performance and adoption in different ecological conditions. 
In: Proc. of the workshop on experiences with modern rice cultivation in Bangladesh. 8-10 June, 1993. P. 93.

Oad, F. C., B. K. Solangi, M. A. Samo, A. A. Lakho, Z. U. Hassan and N. L. Oad. 2001. Growth, yield and relationship of rapeseed under different row spacing. Int. J. Agric. Biol.. 3: 475-476.

Ookawa, T., K. Ishihara. 1993. Varietal difference of the cell wall components affecting the bending stress of the culm in relation to the lodging resistance in paddy rice. Japan Journal of Crop Science. 62: 378-384.

Quddus, M. A. and S. A. N. M. Huda. 1995. A study on the effect of plant spacing and depth of sowing on the formation of tillers and yield of Chandina paddy. Bangladesh J. Agic. Res. 1(2): 7-15.

Rao, K. S. and B. T. S. Moorthy. 2003. Hybrid rice technology for achieved higher yield during dry season in coastal Orissa. Indian Farm. 53(3): 4-5.

Sarkar, S. K., M. A. R. Sarkar, N. Islam and S. K. Paul. 2014. Yield and quality of aromatic fine rice as affected by variety and nutrient management. Journal of the Bangladesh Agricultural University. 12 (2): 279-284

Tyeb, A., S. K. Paul and M. A. Samad. 2013. Performance of variety and spacing on the yield and yield contributing characters of transplanted aman rice. J. Agrofor. Environ. 40(4): 595-597. 
